\title{
NOTES
}

\section{ADMIRALTY LAW: DISTRIGT COURT REFUSES TO FOLLOW EQUAL DIVISION OF DAMAGES RULE IN GASE OF MUTUAL FAULT}

I

IN American admiralty law, damages resulting from a maritime collision attributable to the fault of both parties are apportioned between the parties equally, without regard to the degree of fault of each. Since its inception, various criticisms have been leveled at this "divided damages rule," but courts have continued to adhere stubbornly to its application. The recent case of N.M. Patterson \& Sons, Ltd. v. City of Chicago ${ }^{1}$ breaks with this tradition and apportions damages according to the fault of each party.

The Patterson case arose out of a collision between the ship Torondoc and a drawbridge owned by respondent, City of Chicago. The ship owner, Patterson, filed a libel against the city for damages allegedly caused by the city's failure to maintain their bridge so that it could be properly raised. The city cross-libeled for damages to the bridge asserting the Torondoc's failure to comply with the navigation rules applying to ships proceeding under drawbridges. The District Court for the Northern District of Illinois, finding both the city and the Torondoc negligent in several particulars, ${ }^{2}$ held the

1209 F. Supp. 576 (N.D. IIl. 1962). For other attempts to apportion damages according to fault, see Marine Field Transp. Corp. v. The Tug Ruth, 135 F. Supp. 371 (E.D.N.Y.), aff'd, 23 F.2d 319 (2d Cir. 1955); Tracy Towing Line, Inc. v. City of Jersey City, 105 F. Supp. 910 (D.N.J. 1952); Hudson v. Pittsburgh Plate Glass Co., 263 Fed. 730 (W.D. Pa. 1911); The Mary Ida, 20 Fed. 741 (S.D. Ala. 1884).

${ }^{3}$ The Torondoc was found negligent in proceeding at a speed in excess of the statutory limit for passing under a drawbridge, failing to sound a whistle signal, failing to stop short of a collision, being in the control of an inexperienced master, and in proceeding under the assumption that the drawbridge would open. The rules applicable to the Torondoc were those formulated by the Coast Guard under authority of Navigation Rules for Great Lakes, Chapt. 64, Rule 27 \$3, 28 Stat. 649 (1895), as amended, 1946 Reorg. Plan No. 3, 60 Stat. 1097 (1946), 33 U.S.C. § 243 (1958); those formulated by the Secretary of the Army under authority of Bridges Over Navigable Waters $\$ 6,32$ Stat. 374 (1902), 33 U.S.C. $\$ 499$ (1958); and those formulated in the Municipal Code of the City of Chicago 38-30.

The city's negligence stemmed from failure to inspect and properly maintain the electrical system of the bridge and failure to warn the Torondoc that the bridge had not been adequately opened. The rules of the Secretary of the Army, supra, governed the operation of drawbridges. $209 \mathrm{~F}$. Supp. at 581 .

That the case of a ship in collision with a land object is now treated as a proper subject of admiralty jurisdiction, see Extension of Admiralty Jurisdiction Act, 62 Stat. 496 (1948), 46 U.S.C. $\$ 470$ (1958). 
collision to be two-thirds the fault of the vessel and one-third the fault of the city, and, over the objection of both parties, apportioned damages accordingly. ${ }^{3}$

Realizing that its decision was not in accord with the established admiralty rule, the court endeavored to develop a basis for deviating from such long established precedent. The district judge determined that the equal division rule was adopted from the English courts only to avoid the total bar of contributory negligence in cases where apportionment of fault was impossible. ${ }^{4}$ The principal cases that followed The Catherine, ${ }^{5}$ the leading case establishing the equal division rule, were examined in an effort to show that in no instance had the Supreme Court ever enforced equal division of damages in the face of an express finding of specific degrees of fault. ${ }^{8}$ Moreover, the court found the use of the term "mutual fault" in the early cases meant either "equal fault" or "mutual in specific proportional degrees" and thus, no disharmony existed between this case and the earlier decisions. ${ }^{7}$ From this analysis, the court concluded that no authority explicitly prohibited apportioning damages to fault in a particular instance.

The court next considered the argument that to apportion damages according to fault was fully as arbitrary as the divided damages rule. Negating this contention, Judge Miner pointed to cases and statutes regarding seamen's personal injuries and deaths on the seas in which the plaintiff's own fault is taken into account to mitigate the damages allowed, 8 thus contending that to apportion

${ }^{8} 209$ F. Supp. at 582 . The objection of the city is difficult to grasp because in this case, as decided, it received a judgment of $\$ 888.00$, while under the equal division rule it would have been ordered to pay $\$ 3,168.00$. Possibly it was only trying to avoid reversible error or perhaps it is a further manifestation of admiralty's infatuation with the equal division rule.

Id. at 583-84. It seems that some of the English decisions in favor of equal division arose out of instances where it was nearly impossible to ascertain not only the degree of fault, but also whether both were in fact at fault. See Vaux v. Sheffer, 8 Moore 75, 86, 14 Eng. Rep. 30, 34 (H.L. 1852).

${ }^{5} 58$ U.S. (17 How.) 169 (1854). Here the Supreme Court reversed a lower court finding that only one vessel was at fault, thus reaching the question of damages. The Court then adopted what it felt to be the prevailing English rulc. This result was defended as practical "under the circumstances usually attending these disasters." Id. at 178.

- The cases relied on by the court were The Eugene F. Moran, 212 U.S. 466 (1909); The North Star, 106 U.S. (16 Otto) 17 (1882); and Atlee v. Union Packet Co., 88 U.S. (21 Wall.) 389 (1874).

7209 F. Supp. at 587.

${ }^{8} 209$ F. Supp. at 589-90. Both the Merchant Marine Act of 1920 (Jones Act) $\$ 33$, 41 Stat. 988,1007 (1920), 46 U.S.C. $\$ 688$ (1958), and the Dcath on the High Seas Act 
damages in cases of collision was no more difficult or arbitrary than to do so in personal injury cases. The Max Morris," most often relied upon today for the proposition that personal injury damages are to be apportioned according to fault, ${ }^{10}$ was cited for the broader proposition that the equal division rule should not be blindly followed; that it is at best "rustic," and admiralty courts should be concerned with "enlarged principles of justice and equity" when finding damages in all cases of "marine tort."11

Other courts and commentators have spoken out against the artificiality and arbitrariness of the divided damages rule, some stressing the incongruity of different rules for personal injury and collision damages.12 As early as 1896, an English jurist, concerned with the injustice of the rule in his country, indicated that the then recently decided case, The Max Morris, spelled the end of the equal damages rule in the United States. ${ }^{13}$ However, the Supreme Court's use of

6, 41 Stat. 537-38 (1920), 46 U.S.C. $\$ 766$ (1958), require the trial court to proportion damages in order to mitigate plaintiff's recovery. See generally GrLMore \& BLACK, The LAw OF AdMrRalty (hereinafter referred to as GILMORE \& BLACK) 279-304 (1957). Accord, Pope \& Talbot, Inc. v. Hawn, 346 U.S. 406, 409 (I953); Socony-Vacuum Oil Co. v. Smith, 305 U.S. 424, 428-29 (1939); Ulster Oil Transp. Corp. v. The Matton No. 20, 210 F 2d 106 (2d Cir. I954).

137 U.S. I (1890). A stevedore, not employed by the ship, was injured while loading coal aboard The Max Morris.

10 See cases cited note 8 supra.

11137 U.S. at 12-13.

"See In re Adam's Petition, 237 F2d 884 (2d Cir.), cert. denied, 352 U.S. 977 (1955); Ahlgren v. Red Star Towing \& Transp. Co., 214 F.2d 618 (2d Cir. 1954); Ulster Oil Transp. Corp. v. The Matton No. 20, 210 F.2d 106, 110 (2d Cir. 1954) (dissent); National Bulk Carriers, Inc. v. United States, 183 F.2d 405, 410 (2d Cir. 1950) (dissent); cert. denied, 340 U.S. 865 (1950); The Margaret, 30 F.2d 923 (3d Cir.), cert. denied, 279 U.S. 862 (1929); Huger, The Proportional Damage Rule in Collisions at Sea, 13 CoRnell L.Q. 531 (1928); Staring, Contribution and Division of Damages In Admiralty and Maritime Cases, 45 CAL. L. REv. 304 (1957).

Perhaps the most severe criticism of the equal division rule is the existence of three methods of avoiding its application. The so-called "Major-Minor Fault Rule" allows the lesser fault to be totally discounted, if the court feels it to be insignificant. The doctrine of "Errors in Extremis" permits a vessel under the danger of collision to respond in a way that would be violative of navigation rules under normal circumstances. Lastly, a lesser fault is often held to be a "non-contributory fault." See Griffin, The AMerican Law of Collusion $\$ \$ 214-23,224-26,233-35$ (1949).

Inasmuch as general negligence law applies to liability for maritime collision, the "last clear chance" doctrine has also been used to avoid application of the divided damages rule much in the same manner that it mitigates the contributory negligence rule at common law. To apply the "last clear chance" doctrine there must be a clear "cleavage" between all the foregoing faults and the final "avoidable" fault bringing about the collision. Some cases deny that the doctrine has any place in collision cases. GrIFFIN, op. cit. supra \$215.

13 Franck, Collisions at Sea and Relation to International Maritime Law, 12 L.Q. REv. 260, 272 (1896). However, The Max Morris has not been so interpreted by most courts. Sec, e.g., Ulster Oil Transp. Corp. v. The Matton No. 20, 210 F.2d 106, 110 
both broad and specific language in this opinion makes the specific holding of The Max Morris somewhat cloudy. While there are passages asserting that the equal division rule is not to be indiscriminately applied, ${ }^{14}$ there is likewise language indicating that the Court merely decided that in cases of maritime personal injury, contributory negligence is not a complete bar to recovery. ${ }^{15}$ The interpretation of that opinion in the instant cases is not without support, ${ }^{16}$ but The Max Morris is generally cited only as having. established the proportional damage rule in cases of personal injury. ${ }^{17}$

Even if The Max Morris decision is capable of being interpreted as in the instant case, no court is free from the overwhelming. precedent of the equal division rule. The fact is that out of deference to the Supreme Court, lower courts simply do not apportion damages according to fault, regardless of how prior cases might be manipulated. For example, in The Margaret, ${ }^{18}$ the Third Circuit first modified the decision of the lower court by apportioning damages according to fault. Then, expressing doubt as to the propriety of such a modification on its part, the court on rehearing returned to the equal division rule, not because it lacked the power to. apportion damages, but out of deference to the Supreme Court.10. Likewise, the Second Circuit in Ahlgren v. Red Star Towing o Transp. Co., ${ }^{20}$ while commenting that the rule was patently unjust, held that its enunciation by the Supreme Court and unexplainable-

(2d Cir. 1954) (dissent). See also Halcyon Lines v. Haenn Ship Ceiling \& Refitting Corp., 342 U.S. 282, 284 (1952), where the Court cites the cases dealing with collision. damages and excludes The Max Morris.

It "While the libellant could not be rewarded for his negligence at the expense of the vessel, she should be held responsible for her negligence...." 137 U.S. at 18. (Emphasis added.)

"[I]n cases of marine torts ... courts of Admiralty could exercise a conscientious. discretion, and give or withhold damages upon enlarged principles of justice and' equity ...." 137 U.S. at 13, quoting from The Marianna Flora, 24 U.S. (11 Whent.) 1 , 52 (1826).

${ }_{16}$ "Whether . . . the decree should be for exactly one-half of the damages sustained, or ... be for a greater or less proportion of such damages, is a question not presented for our determination upon this record, and we express no opinion upon it." 137 U.S. at 15 .

10 See The Victory, 68 Fed. 395, 400 (4th Cir. 1895), rev'd on other grounds, 168 . U.S. 410 (1897); GRIFFIN, op. cit. supra note 12, at $\$ \S 245-47$; Staring, supra note 12 , at 342.

${ }^{17}$ See cases cited note 8 supra.

1830 F.2d 923 (3d Cir.), cert. denied, 279 U.S. 862 (1929).

10 Id. at 928.

${ }^{30} 214$ F.2d 618 (2d Cir. 1954). 
longevity required the lower courts to await congressional action or a reversal by the Supreme Court. ${ }^{21}$ The same approach was taken in In re Adams' Petition ${ }^{22}$ in which the district court first apportioned damages on the basis of a decided difference in degrees of fault, but on reargument adopted the position of the Ahlgren case. ${ }^{23}$ The circuit court affirmed the result as the only one which the court was at liberty to affirm regardless of the "inherent injustice of this rule."24

Congress as yet has done little more than the lower courts in dealing with the divided damages rule. In 1910, the United States refused to become a signatory to the Brussels Convention which provides for proportional damages based on degrees of fault. ${ }^{25}$ Furthermore, a recent Senate bill, providing for proportional damages in cases where a finding of such fact could be made, received heavy support from American shipping interests, the American Bar Association; and some practicing attorneys ${ }^{28}$ but was never brought to a vote. While the Senate fell short of enactment of a proportional damage rule, the introduction of the bill and the hearings indicate an awareness in some quarters that the courts will not act in their own initiative to change the equal division rule and that legislative action is required.

All do not agree, however, that the Second and Third Circuits are correct in awaiting congressional or Supreme Court action to resolve this problem. One commentator asserts that the lower court judges should be permitted to manipulate the Supreme Court decisions because in no case has the Supreme Court ever declared the equal division rule to be the exclusive rule as to damages in marine cases. ${ }^{27}$ Another implies this much when he asserts that no "principle" of admiralty would be violated if a proportional damage rule existed side by side with the equal division rule, the latter to be used only when a finding of fact as to proportion of

${ }^{21}$ Id. at $620-21$.

22125 F. Supp. 110 (S.D.N.Y. 1954), aff'd, 237 F.2d 884 (2d Cir. 1956), cert. denied, 352 U.S. 971 (1957).

${ }^{23} 125 \mathrm{~F}$. Supp. at $112,115$.

24 In re Adams' Petition, 237 F.2d 884, 887 (2d Cir. 1956).

${ }^{25}$ Article 4 of the Convention provided for damages in proportion to fault and has been signed or adhered to by most of the major maritime nations except for the United States. Gillmore \& BlAck, op. cit. supra note 8, at 439 . Grifrin, op. cit. supra note 12 , at $\$ 247$.

${ }^{20}$ Hearings Before the Merchant Marine and Fisheries Subcommittee of the Senate Committee on Commerce, 87th Cong., 2d Sess. 24, 30, 149, 150 (1962).

${ }^{2 \tau}$ See Staring, supra note 12 , at $342-43$. 
fault is not possible. ${ }^{28}$ To date one court has followed the instant decision. The District Court for the Northern District of California in $\mathrm{McKeel} v$. Schroeder recently adopted the reasoning of Judge Miner in its entirety and ventured the further opinion that the current Supreme Court would follow the Patterson decision. ${ }^{20}$

While the reasoning of the court in the instant case and the analysis of the last-mentioned writers may be more equitable, the decision of the Second and Third Circuits seems to represent the prevailing judicial attitude toward deviating from the equal division rule. $^{30}$ Inasmuch as Congress has again taken up the matter of admiralty damages, it seems likely that the courts will adopt a waitand-see approach to any far-reaching change on their part. If the approach of the circuit courts is adopted, this case seems destined for reversal and then a denial of certiorari by the Supreme Court, thus, through sheer inertia giving an undesirable rule additional unwarranted support. Such a situation points up the need for definitive congressional action or a clarification by the Supreme Court in order to arrive at an equitable rule and to reach accord with the rest of the maritime nations.

\footnotetext{
${ }^{28}$ See Huger, supra note 12 , at 553-54.

${ }^{20}-$ F. Supp. - (1963). The Court's opinion that the Supreme Court would adopt a proportional damages rule was made without benefit of the Weyerhaeuser decision which was handed down three days later. See note 31 infra.

${ }^{30}$ See GILMORE \& BLACK, op. cit. supra note 8, at 438-42; Staring, supra note 12, at $341-42$.

${ }^{2 x}$ The Supreme Court has denied certiorari several times previously when a circuit court indicated that it could not apportion damages according to fault owing to established precedent. See In re Adams' Petition, 237 F.2d 884 (2d Cir. 1956), cert. denied, 352 U.S. 971 (1957); National Bulk Carriers, Inc. v. United States, 83 F.2d' 405 (2d Cir.), cert. denied, 340 U.S. 865 (1950); The Margaret, 30 F.2d 923 (3d Cir.), cert. denied, 279 U.S. 862 (1929). See also Halcyon Lines v. Haenn Ship Ceiling \& Refitting Corp., 342 U.S. 282, 284 (1952), where the advocates of Supreme Court change can find little hope.

The recent case of Weyerhaeuser Steamship Co. v. United States, 81 U.S.L. WEex 4331 (U.S. April 1, 1963), indicates that the present Supreme Court is not at all dissatisfied with the divided damages rule. The United States had objected to the inclusion of a personal injury award paid by the vessel to a federal employee in the vessel's total damages of which the United States was bound to pay half. The Court, in finding that the divided damages rule overrode the Federal Employees Compensation Act, said of the rule that it was "a rule of admiralty law which, for more than 100 years, has governed with at least equal clarity the correlative rights and duties of two shipowners whose vessels have been involved in a collision in which both were at fault." Id. at 4333.
} 